\title{
Ile655Val of the HER2 gene and its possible predictive value in patients with hereditary breast and ovarian cancer syndrome
}

\author{
Martha Orozco-Quiyono ${ }^{1 *}$, Fidel Espinoza-Contreras ${ }^{2}$, A. Sergio Rodríguez-Cuevas $^{3}$ and \\ Aura Argentina Erazo Valle-Solís ${ }^{4}$
}

${ }^{1}$ Biomedical Research Division, CMN 20 de Noviembre, ISSSTE; ${ }^{2}$ Universidad Autónoma Metropolitana Unidad Xochimilco; ${ }^{3}$ Institute of Breast Diseases (FUCAM); ${ }^{4}$ Teaching and Research Sub-director, CMN 20 de Noviembre, ISSSTE. Ciudad de México, Mexico

\begin{abstract}
Breast cancer is a public health problem that represents the $1^{\text {st }}$ cause of cancer death in Mexican women aged 20 years and over (14.8\%). Metastases occur in 7\% at the time of diagnosis and are usually directed to vital organs such as lung, brain, liver and bone tissue; which leads us to the need to have methods that allow us to diagnose early this phenomenon that is related to a worse prognosis of this disease. We studied the polymorphism at codon 655 of the HER2 gene that results from the change of an isoleucine (ATC) to a valine (GTC), this codon is located in the transmembrane region and may affect the function of this gene when the allele mutated valine, increasing the kinase activation of the HER2 protein, contrary to the decreasing kinase effect with the leucine allele. Our results show that the cases presented a significant difference $(p=0.0006)$ from the isoleucine/valine and valine/valine genotypes compared to controls, in which the predominant genotype was isoleucine/isoleucine.
\end{abstract}

Key words: Hereditary breast and ovarian cancer syndrome. Genetics. Mutation.

Correspondence:

*M.Orozco-Quiyono

E-mail: morozco11@yahoo.com.mx license (http://creativecommons.org/licenses/by-nc-nd/4.0/).

Date of reception: $22-10-2017$

Date of acceptance: 14-04-2018

DOI: 10.24875/j.gamo.M19000170
Available online: 30-05-2019 Gac Mex Oncol. 2018;17:55-60 www.gamo-smeo.com 


\section{Introduction}

Currently, the genetic aspects of cancer, in general, have acquired great relevance. According to National Institute of Statistics and Geography 2016 data, malignant tumors of the breast are regarded as the cancer with the largest presence in 20-year-old and older Mexican women (19.4\%), i.e., three out of every ten women in this age range have breast cancer, with a mortality rate of 15 deaths per 100,000 women aged 20 years and older. The incidence of breast cancer in 2015 in the population of women aged 20 years and older was 14.80 new cases per 100,000 population'.

Metastases occur in $7 \%$ of cases at the time of diagnosis and are usually directed to vital organs such as the lung, brain, liver and bone tissue. In addition, when breast carcinoma is confined to the mammary gland, cure is known to occur in more than $90 \%$ of cases ${ }^{1}$. However, long-term survival depends on the spread of the primary tumor to vital organs (viscera and brain), which decreases 5 -year survival to less than $20 \%$ and, given that current predictive sources of breast cancer clinical behavior for developing metastases (e.g., lymph node status and histological grade) have been inaccurate, there is ongoing research trying to find other predictive markers of this fatal complication. Cases with the same disease stage can show marked differences in treatment response; however, patients undergoing chemotherapy or hormone therapy have the risk of metastasis reduced by approximately one third. Adjuvant treatments of this neoplasm based on histological and clinical characteristics ( $T, N, M)$ improve the survival of patients at early clinical stages with negative lymph nodes to up to $90 \%$. However, advances in recent years in breast cancer molecular classification in four types (luminal A, luminal B, HER 2, basal-like and triple-negative) have been helpful for improving selective treatment according to this classification. Luminal tumors have positive hormone receptors, HER2 tumors show HER2 expression, and basal-like or triple-negative tumors do not express hormone receptors or HER2. Luminal subtype $A$ is the one with the best prognosis, while basal-like has the worst ${ }^{2}$.

Metastasis $^{3}$ is defined as a progressive growth of cells in a site that is discontinuous from the primary tumor; cancer cells can spread to distant organs through the bloodstream and/or lymphatic system.

The HER2 gene, also known as ERBB2/HER2/Neu ${ }^{4}$, is a proto-oncogene that belongs to the family of epidermal growth factor receptors (EGFR) and plays an important role in the pathophysiology of cell growth and differentiation and tissue development, as well as in the process of oncogenesis and metastasis. The HER2 gene is located at chromosome 17 (q11.2-12) and encodes a 1,255-amino acid (185 Kd) transmembrane glycoprotein that activates tyrosine kinase.

In 1986, Yamamoto et al. ${ }^{5}$ described the relationship of HER2 gene overexpression with neoplastic processes that were secondary to a truncated transcript of $2.3 \mathrm{~Kb}$ (normal transcript, 4.6 kilobases), resulting from the deletion of a large part of the extracellular ligand-binding domain, which produced a constitutively active oncogenic receptor that stimulated cell proliferation even at epidermal growth factor (EGF) and related hormones' low concentrations.

EGFR overexpression can affect the cellular phenotype and contribute to its transformation. This HER2 gene overexpression is generally due to amplification of the gene, even with normal numbers of gene copies, with the latter being explainable by transcriptional upregulation or posttranscriptional modification.

In most cases, HER2 gene overexpression has been associated with breast cancer aggressive behavior, with poor prognosis and low survival. Recently, single nucleotide polymorphisms (SNPs) have been described in the proto-oncogene in the region that encodes the transmembrane domain of the protein, located at codons $654^{5}$ and $655^{6-8}$, and whose allelic frequencies for the wild-type Ile/lle allele and for lle/Val wild-type/mutated allele, also referred to as B1 and B2 are reported to be 0.782 and 0.206 , respectively, according to the Genome Database Nomenclature. In addition, a rare allele known as B3 that is $\mathrm{Val} / \mathrm{Val}$ (both mutated), whose allelic frequency is 0.012 , has been described.

Xie D et al. ${ }^{9}$ suggest that the polymorphism in HER2 gene codon 655 is associated with an increased risk for breast cancer, particularly in young women ( $<45$ years) and, in a meta-analysis, lower risk was observed in oriental women in comparison with a higher risk in western women ${ }^{10}$, which suggests that it can be used as an indicator of genetic susceptibility for breast cancer. However, this polymorphism was not associated with poor prognosis in a study conducted in Australian patients with ovarian cancer ${ }^{11}$. The polymorphism in codon $655^{12}$ specifically results from the change of an isoleucine (ATC) for a valine (GTC). This codon is located at the transmembrane region, and in vitro studies of this polymorphism have shown that it can affect HER2 gene function when the mutated valine allele is present, which increases HER2 protein kinase activation, with the kinase decreasing effect being opposite with the leucine allele ${ }^{13}$. In some ethnic 
groups, such as Ashkenazi women, HER2 gene 1655V polymorphism, the mutated valine allele, is reported to be associated with an increase in breast cancer. The frequency of isoleucine-valine heterozygotes and valine-valine homozygotes in Chinese women was $21.7 \%$ and $0.3 \%$ respectively, which are percentages well below those reported in Caucasian women $(40 \%$ and $12 \%$, respectively). These data are consistent with observations reported in other studies indicating that Chinese women have a low risk for developing breast cancer in comparison with Caucasian women, which shows once again that allelic frequencies are different according to the studied population ${ }^{9-22}$; therefore, the results of a studied population cannot be extrapolated to others. The truth is that, with regard to HER2 polymorphisms, the results have been conflicting and have even been inversely related to the risk of breast cancer, especially in older women ( $>45$ years) ${ }^{23}$.

The association of certain polymorphisms with tumors in particular organs might be related to the susceptibility of breast cancer to develop distant metastases in specific organs, depending on the type of polymorphism that is present.

\section{Material and method}

This was a pilot study and the design of the research project is of the prospective, observational, descriptive, open label, case-control type. It was conducted at ISSSTE 20 de Noviembre National Medical Center, and in collaboration with the Institute of Breast Diseases (FUCAM). The study was carried out using peripheral blood samples of 31 patients who agreed to participate in the study after having signed the consent letter and after verifying they met the criteria for hereditary breast and ovarian cancer syndrome (HBOCS) according to the Colima 2010 Breast Consensus, ${ }^{24}$ which include: patients younger than 40 years of age, tumor bilaterality, and a history of breast cancer in first and second-degree relatives, among others. This group of patients has a worse prognosis associated with younger age at cancer presentation, which usually translates into metastasis. The controls were obtained from the ISSSTE 20 de Noviembre National Medical Center Genomic Medicine Department DNA bank.

\section{Total DNA extraction and quantification}

It was carried out using the kit for DNA extraction from biological samples (Qiagen. DNeasy $96^{\mathrm{TM}}$ proto$\mathrm{col})$, following the manufacturer's instructions. Once extracted, total amount in each sample was quantified using a spectrophotometric method (NanoDrop ${ }^{\mathrm{TM}}$ ).

\section{Preparation of agarose gels to confirm total DNA integrity}

Corresponding aliquots were subjected to agarose gel electrophoresis, under appropriate conditions, and the gels were then visualized using an ultraviolet (UV) transilluminator, with the images being captured and their integrity analyzed.

\section{Mutation analysis}

The SNP in the HER2 gene protein transmembrane segment was determined by amplifying the DNA segment according to codon 655 , using the polymerase chain reaction (PCR) technique, followed by the restriction fragment length polymorphism (RFLP) technique ${ }^{25}$. The transmembrane segment, which corresponds to a 148 bp fragment, was amplified by PCR, using gene-specific oligonucleotides (HER2 655 Forward 5'-AGAGCGCCAGCCCTCTGACGTCCAT-3' and HER2 655 Reverse 5'TCCGTTTCCTGCAGCAGTCTCCGCA-3 ${ }^{\prime 13}$ [Invitrogen ${ }^{\mathrm{TM}}{ }^{\mathrm{M}}$ ). A Gradient Palm-Cycler ${ }^{\mathrm{TM}}$ thermal cycler (Corbett Research) was used. The PCR products were subjected to electrophoresis in $2 \%$ agarose gel (UltraPure ${ }^{\mathrm{TM}}$ Agarose Invitrogen ${ }^{\mathrm{TM}}$ Cat. No 16500-500), stained with ethidium bromide (Et-Br) and visualized under UV light in a transilluminator with the sole purpose to assess for integrity and specificity. For the RFLP analysis, the PCR product was subjected to enzymatic digestion with the BsmAl restriction endonuclease (New England BioLabs Cat No R0529S). Two fragments are obtained from BsmAl endonuclease digestion, one of 116bp and another of 32bp for the mutated valine (GTC) allele, which corresponds to one of enzyme 5'-GTCTC (N1). 3' recognition sites; as for the wild-type isoleucine (ATC) allele, there is no recognition by the enzyme, and thus the $148 \mathrm{bp}$ fragment remains intact.

\section{Results}

Total cases were 31 patients with criteria for HBOCS; seven cases were excluded from the study because there was not enough DNA for analysis. There was a total of 24 cases and 24 controls.

Tables 1 and 2 show cases and controls allelic distributions, respectively, showing the difference with regard to the $I / V$ and $V / V$ genotypes in the cases in 
Table 1. HBOC cases genotype distribution

\begin{tabular}{|l|}
\hline Ile/lle homozygote \\
Ile/Val heterozygote \\
\hline Val/Val homozygote
\end{tabular}

Table 2. Controls without cancer genotype distribution

\begin{tabular}{l|c} 
Ile/lle homozygote & 19 \\
\hline Ile/Val heterozygote & 4 \\
\hline Val/Val homozygote & 1 \\
\hline Total & 24
\end{tabular}

comparison with controls, in which wild-type genotype I// predominates. Case and control PCR-RFLPs are shown in figures 1 and 2.

The chi-square statistical test was performed both on cases and controls, with a statistically highly significant result ( $p=0.0006)$. Cases were observed to exhibit the Ile655Val polymorphism in heterozygous and homozygous subjects for the $\mathrm{G}>\mathrm{A}$ mutation in comparison with controls.

The analysis of alleles at one degree of freedom showed a $p \leq 0.0001$ result. The result is also statistically highly significant for the change of the wild-type adenine nucleotide (ATC) for the guanine-mutated nucleotide (GTC) in codon 655 .

Sensitivity of the test was observed to be $70.83 \%$, with a specificity of $79.17 \%$, a positive predictive value (PPV) of $79.17 \%$, a negative predictive value (NPV) of $79.17 \%$ and test concordance of $75.0 \%$.

Table 3 describes the genotyping and allelic frequencies for each clinical stage (CS) of the studied cases. Advanced CS is observed to be most commonly related to the mutated allele, which would be important to consider, since it might be a HBOCS molecular marker. In addition, the fact that that $15(62.5 \%)$ of the 24 cases were diagnosed at late stages stands out.

Table 4 shows the 24 cases and the epidemiological data considered in this study. Patient average age was 44.6 years, with a standard deviation of 11 years (28-68 years of age). Eight of them had a family history of breast cancer, eight had a history of another type of cancer; five had a family history of breast cancer and another type of cancer (ovarian, colon and pancreas, among others) and three had no history of familial cancer.

Only one case was bilateral and its genotype was homozygous for the polymorphism mutation.

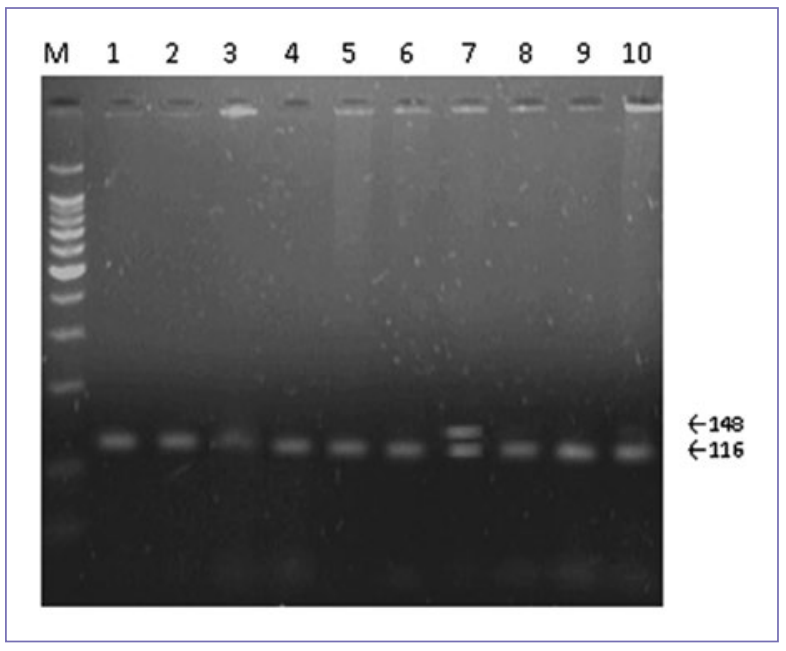

Figure 1. The PCR-RFLP gel of any of the cases with HBOCS is observed; most are homozygous for the $G>A$ mutation and only case 7 was heterozygous for the wildtype and mutated alleles.

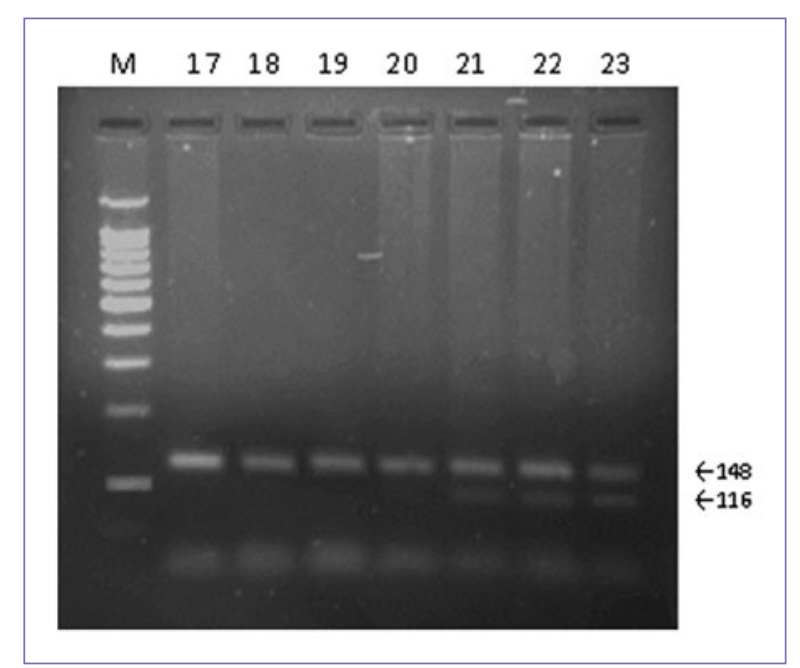

Figure 2. Some HER2 gene Ile655Val polymorphism PCRRFLP controls are observed, as well as the HER2 gene and its genotype, which shows the wild-type homozygote and three heterozygote controls for the $G>A$ change $(21,22,23)$.

\section{Discussion}

The present study is the first one performed in Mexican patients with HBOCS to analyze its relationship with HER2 gene lle655Val polymorphism, which has been studied in several populations of the world and has been associated with predisposition to breast cancer and its severity. Our results, although preliminary, given that the sample is small, are statistically significant with regard to the predictive value of the 
Table 3. Cases genotyping and allelic frequencies

\begin{tabular}{|c|c|c|c|c|c|c|}
\hline $\begin{array}{l}\text { Cases according to clinical stage (CS) } \\
\text { Characteristics }\end{array}$ & No. (\%) & & Genotyping & & \multicolumn{2}{|c|}{ Alleles } \\
\hline Clinical stage & & $\mathrm{A} / \mathrm{A}$ & $A / G$ & $\mathrm{G} / \mathrm{G}$ & A & G \\
\hline NC & $2(8.3)$ & 2 & & & 4 & 0 \\
\hline I & $3(12.5)$ & 1 & & 2 & 2 & 4 \\
\hline IIA & $4(16.66)$ & 1 & 3 & & 5 & 3 \\
\hline IIB & $7(29.16)$ & 1 & & 7 & 2 & 14 \\
\hline IIIA & $3(12.5)$ & 2 & & & 4 & 0 \\
\hline IIIB & $2(8.3)$ & & 1 & 1 & 1 & 3 \\
\hline IIIC & $1(4.16)$ & & & 1 & & 2 \\
\hline IV & $2(8.3)$ & & 1 & 1 & 1 & 3 \\
\hline Total & 24 & 7 (29.16) & $5(20.83)$ & $12(50.0)$ & 19 (39.6) & $29(60.4)$ \\
\hline
\end{tabular}

Table 4. Epidemiological data of a total of 24 cases with HBOCS

\begin{tabular}{|l|c|c|}
\hline Characteristics & Average \pm SD (range) \\
\hline Current age (years) & 33 (28-68) \\
\hline Age at diagnosis (years) & \multicolumn{2}{|c|}{44.6 (de 11) } \\
\hline Evolution time (years) & \multicolumn{2}{|c|}{12.7 (10-16) } \\
\hline Menarche (age) & No. & 33.33 \\
\hline History of breast cancer & 8 & 33.33 \\
\hline History of other cancer & 8 & 20.83 \\
\hline History of two or more cancers* & 5 & 12.5 \\
\hline No history of cancer & 3 & \\
\hline Breastfed (Yes/No) & $15 / 8$ & \\
\hline *Breast cancer and another type of cancer \\
SD: standard deviation.
\end{tabular}

determination of the polymorphism under study in its mutated $\mathrm{G}>\mathrm{A}$ form in homozygous and probably in heterozygous subjects. The $\mathrm{G}>\mathrm{A}$ genotype, both in its heterozygous and homozygous forms, was observed in $70.8 \%$ of the cases, in comparison with controls, where it was only observed in $20.8 \%$.

The cases with metastases to vital organs (clinical stage IV) and their association with the lle655Val polymorphism in its homozygous $\mathrm{G}>\mathrm{A}$ form were observed in young patients, as reported in the literature, and their manifestations were more aggressive.
If the performance of a broader analysis in terms of the number of patients confirms that the presence of HER2 gene lle655Val polymorphism in patients with HBOCS is related to a worse prognosis and associated with metastasis to vital organs, it would be a highly valuable tool in this group of breast cancer patients, since when detecting patients who carry the $\mathrm{G}>\mathrm{A}$ mutation of this polymorphism, they could be offered a more individualized treatment that would improve their quality of life.

\section{Conclusions}

This study demonstrates that the majority of patients with HBOCS carry the valine mutation in the homozygous form in comparison with controls, which in a first analysis suggests that this would be directly associated with the development of breast cancer and, given the criteria involving young patients, and that in most of them tumors occur in aggressive forms, a relationship of the polymorphism with this circumstance would also be established. Although data are clear in this pilot study, we must recognize that it would be interesting to conduct a study in a larger number of cases in order to confirm the observations of this preliminary analysis, as well as carrying out a more detailed study, as it would be with real-time PCR, which has already been proposed by the working group.

\section{Ethical considerations}

Being able to offer breast cancer patients a predictive molecular study that allows a more specific follow-up 
and individualized treatment with improvement of their quality of life, places them in a beneficial state that cannot be ignored, especially considering that this condition is a public health problem that in Mexico is the leading cause of death associated with tumors in women older than 35 years. For the sake of fairness, all these women should be offered the necessary measures to improve their general health status and, in the case of the group under study, patients with HBOCS, which comprises mostly young women in reproductive and productive ages, it is essential to continue in the search for tools that help them lead a dignified and comfortable life and avoid, to the extent possible, death due to complications such as metastases to vital organs, which physically, emotionally and economically wear out the patient and her family.

\section{Conflict of interests}

There is no conflict of interest involving any of the authors.

\section{References}

1. Instituto Nacional de Estadística y Geografía (INEGI) 2016. Estadística a propósito del Día Mundial de la Lucha contra el Cáncer de Mama (19 de octubre). Datos Nacionales. Recuperado el 17 de octubre de 2016, de: http://www.inegi.org.mx/saladeprensa/aproposito/2016/mama2016 0.pdf

2. Cárdenas Sánchez J, Erazo Valle A, Maafs Molina E, Poitevin Chacón A. Consenso nacional sobre diagnóstico y tratamiento del cáncer mamario. Cuarta revisión. Colima 2011. México: Elsevier-Masson Doyma México, S.A.; 2017.

3. Minn AJ, Kang Y, Serganova I, Gupta GP, Giri DD, Doubrovin M, et al. Distinct organ-specific metastatic potential of individual breast cancer cell and primary tumors. J Clin Invest. 2005:115(1):44-55.

4. Frank B, Hemminki K, Wirtenberger M, Bermejo JL, Bugert P, Klaes R, et al. The rare ERBB2 variant lle654Val is associated with an increased familial breast cancer risk. Carcinogenesis. 2005;26(3):643-7.

5. Yamamoto T, Ikawa S, Akiyama T, Semba K, Nomura N, et al. Similarity of protein encoded by the human c-erb-B-2 gene to epidermal growth factor receptor. Nature. 1986;319(6050):230-4.

6. Fleishman SJ, Schlessinger J, Ben-Tal N. A putative molecular-activation switch in the transmembrane domain of erbb2. Proc Natl Acad Sci USA. 2002;99;15937-40.
7. Ehsani A, Low J, Wallace RB, Wu AM. Characterization of an allele of the human ERBB2 gene by allele-specific competition hybridization. Genomics. 1993;15(2):426-9.

8. Rutter JL, Chatterjee N, Wacholder S, Struewing J. The HER2 1655V polymorphism and breast cancer risk in Ashkenazim. Epidemiology. 2003;14(6):694-700.

9. Xie D, Shu XO, Deng Z, Wen WQ, Creek KE, Dai Q, et al. Population-based, case-control study of HER2 genetic polymorphism and breast cancer risk. J Natl Cancer Inst. 20001;92(5):412-7.

10. Tao W, Wang $\mathrm{CH}$, Han R, Jiang H. HER2 codon 655 polymorphism and breast cancer risk: a meta-analysis. Breast Cancer Res Treat. 2009;114:371-6.

11. Watrowski R, Castillo-Tong DC, Schuster E, Fischer MB, Speiser P, Zeillinger R. Association of HER2 codon 655 polymorphism with ovarian cancer. Tumor Biol. 2016:37:7239-44.

12. An HJ, Kim NK, Oh D, Kim SH, Park MJ, Jung MY, et al. Her2 genotype and breast cancer progression in Korean women. Pathol Int. 2005;55(2):48-52.

13. Han X, Diao L, Xu Y, Xue W, Ouyang T, Li J, et al. Association between the HER2 lle655Val polymorphism and response to trastuzumab in women with operable primary breast cancer. Ann Oncol. 2014;25(6):1158-64.

14. Pinto D, Vasconcelos A, Costa S, Pereira D, Rodrigues H, Lopes C, et al. HER2 polymorphism and breast cancer risk in Portugal. Eur $\mathrm{J}$ Cancer Prev. 2004;13(3):177-81

15. Ren Z, Cai Q, Shu XO, Cai H, Li C, Yu H, et al. Genetic polymorphisms in the IGFBP3 gene: association with breast cancer risk and blood IGFBP-3 protein levels among Chinese women. Cancer Epidemiol Biomarkers Prev. 2004;13(8):1290-5.

16. Millikan R, Eaton A, Worley K, Biscocho L, Hodgson E, Huang WY, et al. HER2 codon 655 polymorphism and risk of breast cancer in African Americans and whites. Breast Cancer Res Treat. 2003;79(3):355-64.

17. Justenhoven C, Hamann U, Pesch B, Harth V, Rabstein S, Baisch C, et al. ERCC2 genotypes and a corresponding haplotype are linked with breast cancer risk in a German population. Cancer Epidemiol Biomarkers Prev. 2004;13(12):2059-64

18. Rutter JL, Chatterjee N, Wacholder S, Struewing J. The HER2 I655V polymorphism and breast cancer risk in Ashkenazim. Epidemiology. 2003;14(6):694-700.

19. Kamali-Sarvestani E, Talei AR, Merat A. lle to Val polymorphism at codon 655 of HER-2 gene and breast cancer risk in Iranian women. Cancer Lett. 2004;215(1):83-7.

20. Benusiglio PR, Lesueur F, Luccarini C, Conroy DM, Shah M, Easton DF, et al. Common ERBB2 polymorphisms and risk of breast cancer in a white British population: a case-control study. Breast Cancer Res. 2005;7(2):R204-9

21. Parvin S, Islam MS, Al-Mamun MM, Islam MS, Ahmed MU, Kabir ER, et al. Association of BRCA1, BRCA2, RAD51, and HER2 gene polymorphisms with the breast cancer risk in the Bangladeshi population. Breast Cancer. 2017;24(2):229-37.

22. Watrowski R, Castillo-Tong DC, Wolf A, Schuster E, Fischer MB, Speiser $\mathrm{P}$, et al. HER2 Codon 655 (lle/Val) Polymorphism and Breast Cancer in Austrian Women. Anticancer Res. 2015;35(12):6667-70.

23. Nelson SE, Gould MN, Hampton JM, Trentham-Dietz A. A case-control study of the HER2 lle655Val polymorphism in relation to risk of invasive breast cancer. Breast Cancer Res. 2005;7(3):R357-64.

24. Tercera Revisión del Consenso sobre Diagnóstico y Tratamiento del Cáncer Mamario (tercera de tres partes). Ginecol Obstst Mex. 2010;78(3):199-212.

25. Papewalis J, Nikitin AYu, Rajewsky MF. G to A polymorphism at amino acid codon 655 of the human erbbb-2/HER2 gene. Nucleic Acid Research. 1991;19(19):5452. 